\title{
Histologic Findings of the Parotid Gland and Bicarbonate Content in Parotid Saliva of Dogs with Experimentally Produced Pancreatitis*
}

\author{
Goro Kakizaki, $\uparrow$ Noboru Noto,$\uparrow$ Yoshiyuki Fujiwara, $\uparrow$ \\ Enchi Kato, $\uparrow$ Takuzo Ishidate $\ddagger$ and Takayuki Sarto \\ Department of Surgery, $\uparrow$ and Department of Pathology, $\ddagger$ \\ Akita University School of Medicine, Akita, and Department \\ of Surgery, Tohoku University School of Medicine, Sendai§
}

\begin{abstract}
Kakizaki, G., Noto, N., Fujiwara, Y., Kato, E., Ishidate, T. and Sarto, T. Histologic Findings of the Parotid Gland and Bicarbonate Content in Parotid Saliva of Dogs with Experimentally Produced Pancreatitis. Tohoku J. exp. Med., 1972, 108 (2), 165-177 — Degenerative changes of the parotid gland and a marked decrease of the maximum bicarbonate concentration in parotid saliva were found in dogs with acute experimental pancreatitis. __ bicarbonate; experimental pancreatitis; parotid gland
\end{abstract}

In a series of experimental study on the correlation between the pancreas and parotid gland, the authors demonstrated in experiments of rats (Kakizaki et al. 1971,1972 a, b) that acute pancreatitis caused atrophic changes and low amylase content of the parotid gland, and that histologic findings and amylase content of the parotid gland changed parallel to the severity of pancreatic lesions in the repairing period of acute pancreatitis and furthermore that perforative peritonitis and ileus themselves could not exert a direct effect upon histologic changes of the parotid gland.

In the present study of ours, experimental production of acute pancreatitis was made in dogs and histologic examination of the pancreas and parotid gland and biochemical examination of parotid saliva were done.

\section{Materials and Methods}

Four mongrel dogs (Nos. 1,2,3 and 4) were used.

No. 2 , a male, $11.6 \mathrm{~kg}$ of body weight, was examined for biochemical changes in saliva and blood before, 19 hours and 42 hours after the operation for production of acute pancreatitis, and for histologic changes of the pancreas and parotid glands 42 hours after the operation.

No. 3 , a female, $11 \mathrm{~kg}$ of body weight, was used for biochemical study of saliva and blood before and 73 hours after the operation and for the histologic examination of the pancreas and parotid glands 73 hours after the operation.

Received for publication, March 6, 1972.

* Experimental study on the correlation between the pancreas and parotid gland, 4th Report.

$\dagger$ Director: Prof. T. Maeta. 
No. 4, a male, $10 \mathrm{~kg}$ of body weight, was examined for the same items as in No. 3, before and 28 hours after the operation.

No. 1, a male, $8 \mathrm{~kg}$ of body weight, was used for the histologic examination of the pancreas and parotid gland as a control (Figs. 1 and 2).

Methods for biochemical examination of saliva and blood, and for histologic examination

Collected saliva was subjected to the measurement of volume, $\mathrm{pH}$, bicarbonate, sodium, chloride and potassium.

Blood drawn from the femoral vein was used for measurement of serum amylase, $\mathrm{pH}$, hematocrit, electrolytes (sodium, chloride and potassium), total protein and plasma protein fractions.

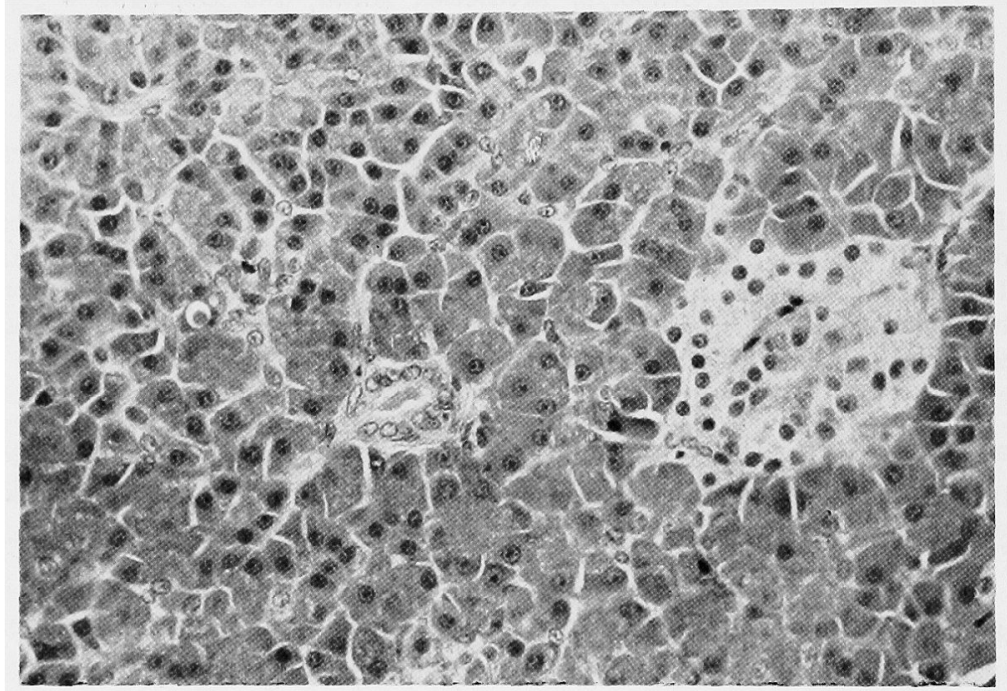

Fig. 1. Photomicrograph of the pancreas from Dog No. 1. H.E. stain.

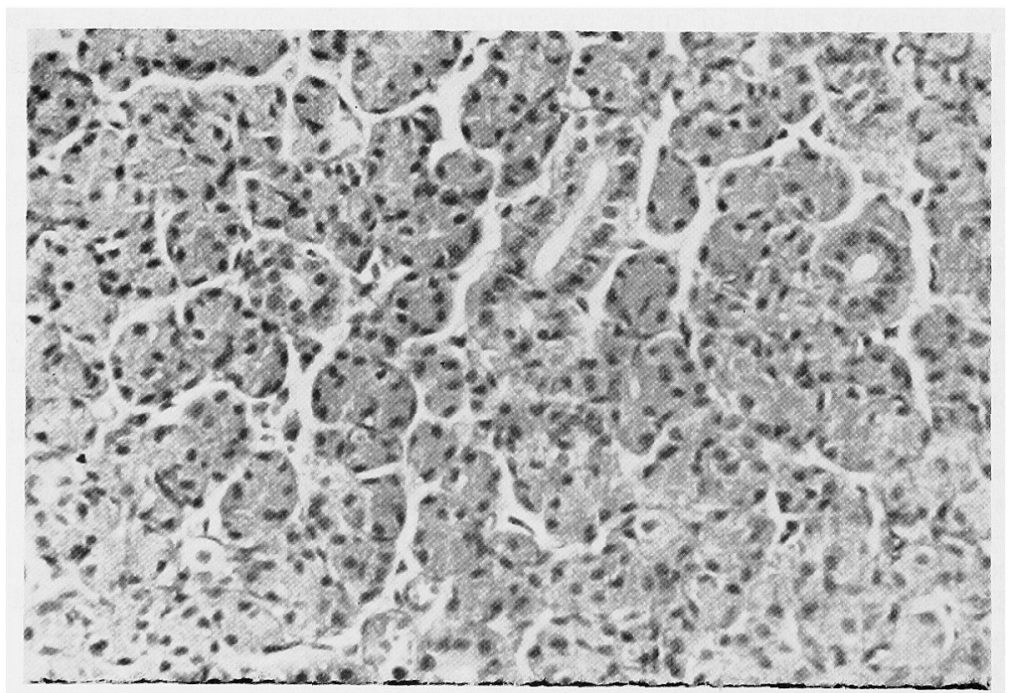

Fig. 2. Photomicrograph of the parotid gland from Dog No. 1. H.E. stain. 
Bicarbonate was determined by titration method of Van Slyke et al. (1919), sodium and potassium by the method of flame photometer (Hald 1947), chloride by Schales and Schales' method (1941) and serum amylase values according to Somogyi's method (1938). $\mathrm{pH}$ was determined by the method of glass electrode (Andersen et al. 1960), hematocrit by the method of McGovern et al. (1955), total protein by light scattering method (Tietze and Neurath 1952) and plasma protein fractions according to cellulose acetate electrophoretic techniques (Kohn 1962).

The pancreas and parotid glands were fixed in $10 \%$ formalin and stained with hemat. oxylin-eosion for the histologic examination.

\section{Method for collection of saliva}

The animal was anesthetized with nembutal injected intravenously in a dose of 35 mg per $\mathrm{kg}$ of body weight, placed on its side and the other Stenson's duct was cannulated. The cannula was made by cutting off the tip of a hypodermic needle of suitable bore, and polishing the end. It was placed in the duct and fixed by silk and connected to the polyethylene tube. Then, pilocarpine was injected intramuscularly in a dose of $0.5 \mathrm{mg}$ per $\mathrm{kg}$ of body weight. As soon as salivary secretion began, saliva was collected for forty to sixty minutes at every five minute intervals.

\section{Method for production of acute pancreatitis}

The abdomen was opened and the duodenum incised longitudinally about $5 \mathrm{~cm}$ in length. Paying attention not to injure the common bile duot, the ventral pancreatic duot was ligated at the site close to the duodenum by a silk thread. Then, polyethylene tube was inserted into the dorsal pancreatic duct from the dorsal duodenal papilla and a mixture consisting of $2 \mathrm{ml}$ of bile aspirated from the gallbladder and $2 \mathrm{ml}$ of Trypsin $(10,000$ unit), Mochida pharmaceutical company, were poured into the tube. As soon as the tube was drawn out, the dorsal pancreatic duct was ligated at the site close to the duodenum by a silk thread. After closure of the incised duodenum, the abdomen was closed.

\section{Results}

$\operatorname{Dog}$ No. 2

Changes in chemical composition of blood and saliva: As shown in Table 1, serum amylase showed higher values 19 and 42 hours after the operation than before that. In plasma protein fractions, albumin and $A / G$ were lower after the operation, but $\alpha_{1}$ and $\alpha_{2}$ globulins were higher after the operation. Serum $\mathrm{pH}$, hematocrit, electrolytes and total protein showed no significant changes after the operation.

The salivary secretion after the injection of pilocarpine occurred from one, ten and four minutes before, and 19 and 42 hours after the operation, revealing that the beginning time of salivary secretion was delayed after the operation. As shown in Table 2, the total volume of saliva amounted to $22.0 \mathrm{ml}$ for 40 minutes $(0.5 \mathrm{ml}$ for a minute), $9.8 \mathrm{ml}$ for 35 minutes $(0.28 \mathrm{ml}$ for a minute) and $12.7 \mathrm{ml}$ for 40 minutes $(0.32 \mathrm{ml}$ for a minute) before, 19 and 42 hours after the operation, indicating a marked reduction of salivary volume after the operation. The maximum bicarbonate concentration in saliva was $56 \mathrm{mEq} / \mathrm{L}, 52 \mathrm{mEq} / \mathrm{L}$ and $35 \mathrm{mEq} /$ $\mathrm{L}$ before, 19 and 42 hours after the operation. Electrolytes and $\mathrm{pH}$ of saliva showed no changes after the operation.

Autopsy findings: A considerable amount of serous and bloody ascites was 
TABLE 1. Chemical composition

\begin{tabular}{|c|c|c|c|c|}
\hline $\begin{array}{l}\text { Lapse of time after the } \\
\text { operation for producing } \\
\text { acute pancreatitis }\end{array}$ & $\begin{array}{l}\text { Conditions for blood } \\
\text { sampling }\end{array}$ & $\begin{array}{l}\text { Serum amylase } \\
(\mathrm{mg} / 100 \mathrm{ml})\end{array}$ & $\mathrm{pH}$ & $\begin{array}{r}\mathrm{Ht} \\
(\%)\end{array}$ \\
\hline \multirow{2}{*}{ Before } & $\begin{array}{l}\text { Before injection of } \\
\text { pilocarpine }\end{array}$ & 1,609 & 7.6 & 36 \\
\hline & $\begin{array}{l}21 \mathrm{~min} \text {. after injec- } \\
\text { tion of pilocarpine }\end{array}$ & 2,048 & 7.6 & 44 \\
\hline \multirow{2}{*}{19 hours } & $\begin{array}{l}\text { Before injection of } \\
\text { pilocarpine }\end{array}$ & 9,322 & 7.5 & 48 \\
\hline & $\begin{array}{l}28 \mathrm{~min} \text {. after injec- } \\
\text { tion of pilocarpine }\end{array}$ & 9,530 & 7.5 & 49 \\
\hline \multirow{2}{*}{42 hours } & $\begin{array}{l}\text { Before injection of } \\
\text { pilocarpine }\end{array}$ & 11,698 & 7.6 & 39 \\
\hline & $\begin{array}{l}22 \mathrm{~min} \text {. after injec- } \\
\text { tion of pilocarpine }\end{array}$ & 11,842 & 7.6 & 42 \\
\hline
\end{tabular}

TABLE 2. Volume and chemical composition

\begin{tabular}{|c|c|c|c|c|c|c|c|c|c|}
\hline \multirow[b]{2}{*}{ (B) } & \multicolumn{3}{|c|}{ Volume (ml) } & \multicolumn{3}{|c|}{$\mathrm{pH}$} & \multicolumn{3}{|c|}{$\mathrm{HCO}_{3}(\mathrm{mEq} / \mathrm{L})$} \\
\hline & Before & $\begin{array}{c}19 \\
\text { hours }\end{array}$ & $\begin{array}{c}42 \\
\text { hours }\end{array}$ & Before & $\begin{array}{c}19 \\
\text { hours }\end{array}$ & $\begin{array}{c}42 \\
\text { hours }\end{array}$ & Before & $\begin{array}{c}19 \\
\text { hours }\end{array}$ & $\begin{array}{c}42 \\
\text { hours }\end{array}$ \\
\hline 5 & 4.1 & 2. 8 & 1.1 & 7.6 & 7.6 & 7.6 & 44 & 43.5 & 23 \\
\hline 10 & 3.7 & 2.1 & 2. 8 & 7.6 & 7.6 & 7.6 & 53 & 52 & 35 \\
\hline 15 & 2.7 & 1.1 & 1.8 & 7.6 & 7.6 & 7.6 & 51 & 47 & 35 \\
\hline 20 & 3.6 & & 1.8 & 7.6 & & 7.6 & 50 & & 33 \\
\hline 25 & 2.3 & 1.8 & 1.8 & 7.6 & 7.6 & 7.6 & 56 & 40 & 27 \\
\hline 30 & 2.4 & & 1.3 & 7. 6 & & 7. 6 & 54 & & 24 \\
\hline 35 & 1.5 & 2.0 & 1.1 & 7.6 & 7.6 & 7.6 & 53 & 37 & 23 \\
\hline 40 & 1.7 & & 1.0 & 7.6 & & 7.6 & 53 & & 23 \\
\hline
\end{tabular}

(A) Lapse of time after the operation for producing acute pancreatitis

(B) Time of

found in the abdominal cavity. Fatty necroses were present around the pancreas. The pancreas was edematously swollen and hemorrhagic. Both parotid glands were edematous and atrophic.

\section{Histologic findings}

Pancreas: In pancreatic head, there was bleeding around the pancreatic duct and in some of the acinus. The acinus was markedly edematous. In pancreatic body, necrobioses or necroses were obviously noticed and infiltration of granulocytes and round cells was moderately noticed in a part of peripancreatic fatty tissues and interstitial tissues. There were also fatty necroses in the peripancreatic tissues (Fig. 3). In pancreatic tail, infiltration of inflammatory cells and fatty necroses were limited in a part of the peripancreatic tissue.

Parotid glands: An obvious finding was an atypical arrangement of the 
of blood of Dog No. 2

\begin{tabular}{|c|c|c|c|c|c|c|c|c|c|c|}
\hline \multicolumn{3}{|c|}{$\begin{array}{l}\text { Electrolyte } \\
(\mathrm{mEq} / \mathrm{L})\end{array}$} & \multirow{2}{*}{$\begin{array}{c}\text { Total } \\
\text { protein } \\
(\mathrm{g} / 100 \mathrm{ml})\end{array}$} & \multirow{2}{*}{$\mathrm{A} / \mathrm{G}$} & \multicolumn{6}{|c|}{ Plasma protein fractions } \\
\hline $\mathrm{Na}$ & $\mathrm{Cl}$ & K & & & albumin & $a_{1}$ & $a_{2}$ & $\beta_{1}$ & $\beta_{2}$ & $\gamma$ \\
\hline 135 & 104 & 5.8 & 5.6 & 0.71 & 41.5 & 8.5 & 13.5 & 13.0 & 11.5 & 12.0 \\
\hline 140 & 103 & 4.9 & 6.2 & 0.64 & 39.0 & 9.5 & 14.5 & 13.0 & 13.0 & 11.0 \\
\hline 135 & 101 & 5.5 & 7.0 & 0.64 & 39.0 & 10.0 & 18.0 & 10.0 & 13. 0 & 10.0 \\
\hline 156 & 100 & 5.0 & 7.5 & 0.56 & 36.0 & 11.0 & 19.0 & 10.0 & 15.0 & 9.0 \\
\hline 154 & 110 & 5.9 & 5.4 & 0.45 & 31.0 & 17.5 & $22 . \overline{5}$ & 9.5 & 11.5 & 8.0 \\
\hline 150 & 109 & 6.8 & 5.8 & 0.49 & 33.0 & 12.5 & 17.5 & 9.5 & 15.0 & 12.5 \\
\hline
\end{tabular}

of saliva of Dog No. 2

\begin{tabular}{|c|c|c|c|c|c|c|c|c|}
\hline \multicolumn{3}{|c|}{$\mathrm{Na}(\mathrm{mE} q / \mathrm{L})$} & \multicolumn{3}{|c|}{$\mathrm{Cl}(\mathrm{mEq} / \mathrm{L})$} & \multicolumn{3}{|c|}{$\mathrm{K}(\mathrm{mEq} / \mathrm{L})$} \\
\hline Before & $\begin{array}{c}19 \\
\text { hours }\end{array}$ & $\begin{array}{c}42 \\
\text { hours }\end{array}$ & Before & $\begin{array}{c}19 \\
\text { hours }\end{array}$ & $\begin{array}{c}42 \\
\text { hours }\end{array}$ & Before & $\begin{array}{c}19 \\
\text { hours }\end{array}$ & $\begin{array}{c}42 \\
\text { hours }\end{array}$ \\
\hline 108 & 113 & 120 & 77.5 & 67.6 & 77.5 & 8.4 & 8.4 & 8.0 \\
\hline 106 & 90 & 124 & 63.5 & 43.0 & 83.5 & 5.6 & 5.6 & 4.8 \\
\hline 113 & & 150 & 67.5 & & 65.5 & 5.6 & & 5.0 \\
\hline 122 & & 140 & 67.5 & & 60.0 & 5.6 & & 7.0 \\
\hline 123 & 92 & 133 & 62.5 & 46.5 & 63.5 & 5.6 & 0.0 & 6.4 \\
\hline 124 & & 140 & 64.0 & & 47.5 & 5.8 & & 3.6 \\
\hline 125 & 67 & 133 & 67.6 & 44.5 & 37.5 & 5.4 & 0.0 & 3.6 \\
\hline 125 & & & 64.0 & & & 4.8 & & \\
\hline
\end{tabular}

saliva sampling (min)

glandular cells in which vacuolation and disappearance of zymogen granules were found. The debris of epithelial cells was noticed markedly in peripheral parotid ducts (Fig. 4).

The results in Dog No. 2 were summarized as follows. In fourty-two hours after experimental production of acute panceatitis, histologic findings obviously showed necroses in the pancreatic body and degenerative changes in the parotid gland. The volume and maximum bicarbonate concentration of parotid saliva were markedly reduced. In nineteen hours after experimental production of acute pancreatitis, however, the maximum bicarbonate concentration of parotid saliva showed no significant difference in comparison with the control, though the flow of parotid saliva was reduced. 


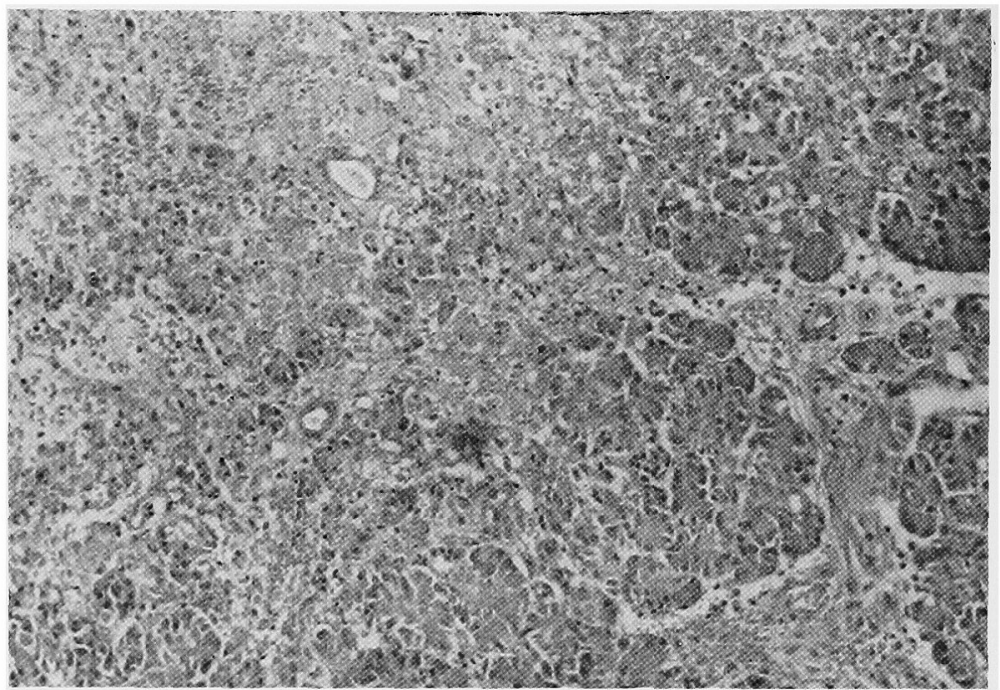

Fig. 3. Photomicrograph of the pancreatic body from Dog No. 2. The acini are broken down and necroses of glandular cells noticed extensively. The acini fell in necrobioses and relatively normal acini are irregularly remaining around necroses, and among them the infiltration of inflammatory cells accompanied by polynuclear leucocytes is noticed.

(H.E. stain)

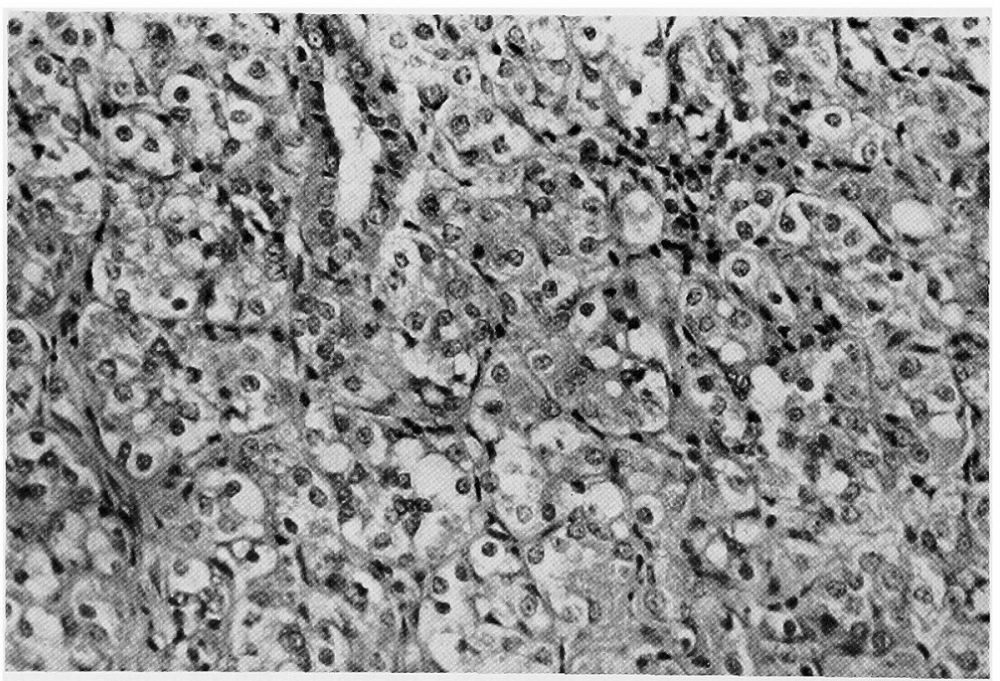

Fig. 4. Photomicrograph of the parotid gland from Dog No. 2. Obvious findings are the vacuolation of glandular cells and the disapearance of zymogen granules. (H.E. stain)

$\operatorname{Dog}$ No. 3

Changes in chemical composition of blood and saliva: Serum amylase was 1,958 $\mathrm{mg} / 100 \mathrm{ml}$ and $11,250 \mathrm{mg} / 100 \mathrm{ml}$ before and 72 hours after the operation, respectively. 


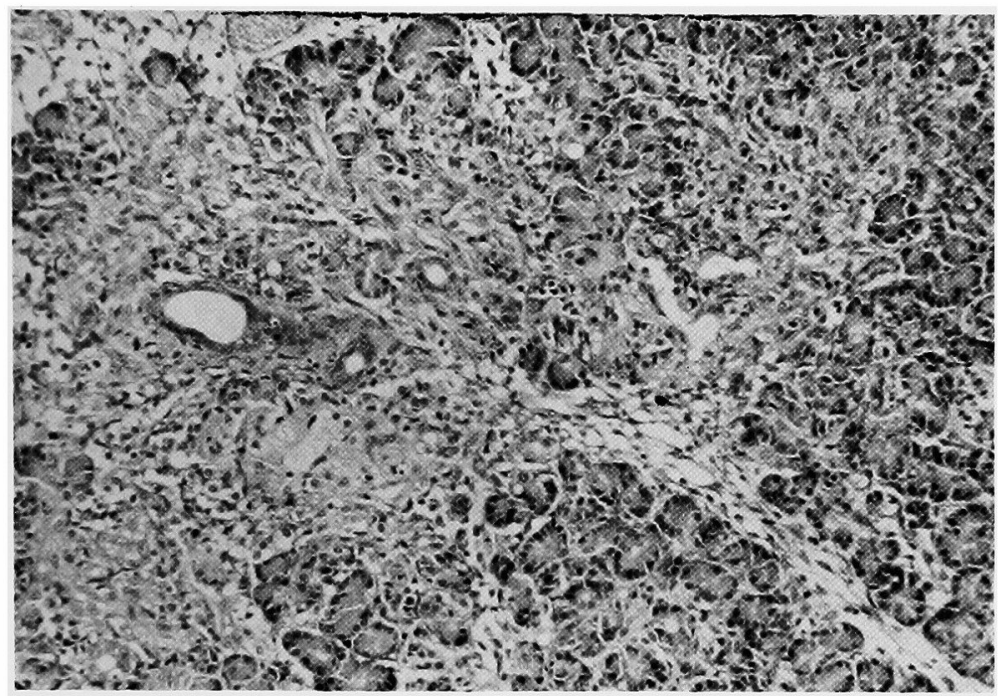

Fig. 5. Photomicrograph of the pancreatic tail from Dog No. 3. Necrosis is noticed similiar to the histologic findings of Fig. 3. H.E. stain.

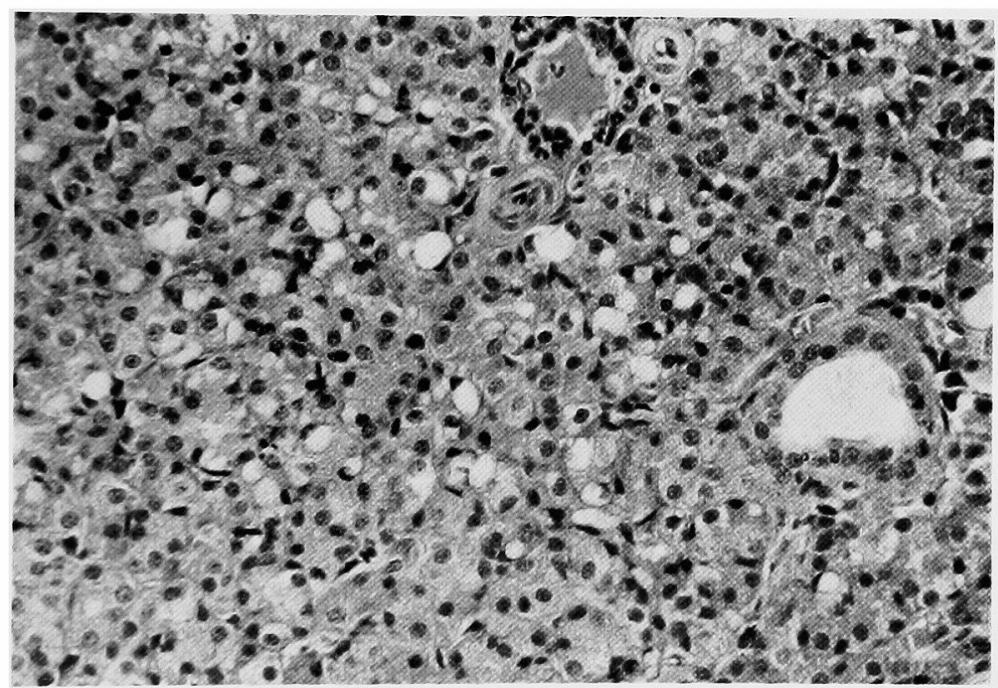

Fig. 6. Photomicrograph of the parotid gland from Dog No. 3. The vacuolation of glandular cells is scattered. H.E. stain.

The beginning of salivary secretion after injection of pilocarpine occurred from one and three minutes before and 73 hours after the operation. As shown in Table 3, the total flow was $36.0 \mathrm{ml}$ for 50 minutes $(0.72 \mathrm{ml}$ for a minute) and 28.8 $\mathrm{ml}$ for 60 minutes $(0.48 \mathrm{ml}$ for a minute) before and 73 hours after the operation, respectively. The maximum bicarbonate concentration of saliva was $83 \mathrm{mEq} / \mathrm{L}$ and $41 \mathrm{mEq} / \mathrm{L}$ before and after the operation, respectively. The values for chloride showed a tendency to increase postoperatively and no significant changes were 
TABLE 3. Volume and chemical

\begin{tabular}{c|c|c|c|c}
\hline \multirow{2}{*}{$\begin{array}{c}\text { Time of saliva } \\
\text { sampling (min) }\end{array}$} & \multicolumn{2}{|c|}{ Volume (ml) } & \multicolumn{2}{c}{$\mathrm{HCO}_{\mathbf{3}}(\mathrm{mEq} / \mathrm{L})$} \\
\cline { 2 - 4 } & $\begin{array}{c}\text { Before the } \\
\text { operation }\end{array}$ & $\begin{array}{c}\text { 73 hours after } \\
\text { the operation }\end{array}$ & $\begin{array}{c}\text { Before the } \\
\text { operation }\end{array}$ & $\begin{array}{c}73 \text { hours after } \\
\text { the operation }\end{array}$ \\
\hline 5 & 6.0 & 0.3 & 54 & \\
10 & 8.2 & 2.2 & 82 & 35 \\
15 & 4.7 & 2.7 & 83 & 39 \\
20 & 2.7 & 3.9 & 66 & 41 \\
25 & 2.4 & 3.3 & 61 & 39 \\
30 & 1.9 & 2.7 & 60 & 38 \\
35 & 2.2 & 3.1 & 52 & 36 \\
40 & 2.5 & 3.0 & 82 & 34 \\
45 & 2.8 & 3.0 & 82 & 34 \\
50 & 2.6 & 2.3 & & 34 \\
55 & & 2.3 & & 33 \\
60 & & &
\end{tabular}

TABLE 4. Volume and chemical

\begin{tabular}{c|c|c|c|c}
\hline \multirow{2}{*}{$\begin{array}{c}\text { Time of saliva } \\
\text { sampling (min) }\end{array}$} & \multicolumn{2}{|c|}{ Volume (ml) } & \multicolumn{2}{c}{$\mathrm{HCO}_{3}(\mathrm{mEq} / \mathrm{L})$} \\
\cline { 2 - 5 } & $\begin{array}{c}\text { Before the } \\
\text { operation }\end{array}$ & $\begin{array}{c}\text { 28 hours after } \\
\text { the operation }\end{array}$ & $\begin{array}{c}\text { Before the } \\
\text { operation }\end{array}$ & $\begin{array}{c}28 \text { hours after } \\
\text { the operation }\end{array}$ \\
\hline 5 & 4.2 & 0.7 & 54 & 28 \\
10 & 4.2 & 2.1 & 57 & 42 \\
15 & 3.2 & 1.5 & 57 & 46 \\
20 & 2.9 & 1.2 & 62 & 44 \\
25 & 3.6 & 1.2 & 63 & 48 \\
30 & 1.5 & 1.0 & 65 & 46 \\
35 & 2.2 & 1.1 & 64 & 49 \\
40 & 1.8 & 0.9 & 60 & 48 \\
45 & 2.0 & 1.0 & 67 & 48 \\
50 & 1.8 & 0.9 & 60 & 49 \\
55 & 1.9 & 1.0 & 60 & 50 \\
60 & & 0.8 & &
\end{tabular}

noticed in sodium and potassium before and after the operation.

Autopsy findings: There were a considerable amount of serous and bloody ascites and scattered areas of fatty necroses in the abdominal cavity. The consistency of the pancreas was hard, specially in the body and tail of the pancreas. An abscess, $5 \times 5 \mathrm{~cm}$ in diameter, was found in the pancreatic tail. Both parotid glands were atrophic and edematous.

\section{Histologic findings}

Pancreas: There were marked edema, necroses, and abscess in a part of the pancreatic tail (Fig. 5). The body and head of the pancreas were edematous.

Parotid glands: The vacuolation of glandular cells was scattered, the grade of which was milder than that in Dog No. 2 (Fig. 6). There was an infiltration of polynuclear leucocytes into some of the periductal tissues.

The results in Dog No. 3 were summarized as follows. In seventy-three hours 
composition of saliva of Dog No. 3

\begin{tabular}{|c|c|c|c|c|c|}
\hline \multicolumn{2}{|c|}{$\mathrm{Na}(\mathrm{mEq} / \mathrm{L})$} & \multicolumn{2}{|c|}{$\mathrm{Cl}(\mathrm{mEL} / \mathrm{L})$} & \multicolumn{2}{|c|}{$\mathrm{K}(\mathrm{mEq} / \mathrm{L})$} \\
\hline $\begin{array}{l}\text { Before the } \\
\text { oqeration }\end{array}$ & $\left|\begin{array}{l}73 \text { hours after } \\
\text { the operation }\end{array}\right|$ & $\begin{array}{c}\text { Before the } \\
\text { operation }\end{array}$ & $\begin{array}{l}73 \text { hours after } \\
\text { the operation }\end{array}$ & $\begin{array}{c}\text { Before the } \\
\text { operation }\end{array}$ & $\begin{array}{l}73 \text { hours after } \\
\text { the operation }\end{array}$ \\
\hline 71 & & 30.1 & & 8.2 & \\
\hline 74 & 55 & 17.0 & 37.0 & 4.4 & 8.8 \\
\hline 78 & 82 & 14.6 & 37.6 & 5.4 & 6.0 \\
\hline 62 & 76 & 12.5 & 37.6 & 5.8 & 6.2 \\
\hline 49 & 86 & 10.3 & 37.6 & 7.4 & 6.4 \\
\hline 35 & 65 & 7.6 & 29.2 & 7.5 & 4.6 \\
\hline
\end{tabular}

composition of saliva of Dog No. 4

\begin{tabular}{|c|c|c|c|c|c|}
\hline \multicolumn{2}{|c|}{$\mathrm{Na}(\mathrm{mEq} / \mathrm{L})$} & \multicolumn{2}{|c|}{$\mathrm{Cl}(\mathrm{mEq} / \mathrm{L})$} & \multicolumn{2}{|c|}{$\mathrm{K}(\mathrm{mEq} / \mathrm{L})$} \\
\hline $\begin{array}{c}\text { Before the } \\
\text { operation }\end{array}$ & $\begin{array}{l}28 \text { hours after } \\
\text { the operation }\end{array}$ & $\begin{array}{l}\text { Before the } \\
\text { operation }\end{array}$ & $\begin{array}{l}28 \text { hours after } \\
\text { the operation }\end{array}$ & $\begin{array}{c}\text { Before the } \\
\text { operation }\end{array}$ & $\begin{array}{l}28 \text { hours after } \\
\text { the operation }\end{array}$ \\
\hline 72 & 80 & 50 & 48 & 8.4 & 86 \\
\hline 94 & & 48 & & 6.2 & \\
\hline 93 & 78 & & 43 & 4.6 & 5.2 \\
\hline 131 & $\gamma$ & 52 & $\gamma$ & 6.4 & $\gamma$ \\
\hline 137 & & 52 & & 6.8 & \\
\hline 128 & 73 & 43 & 40 & 6.8 & 5.6 \\
\hline
\end{tabular}

after experimental production of acute pancreatitis, obvious histologic findings were necroses in the pancreatic tail and degeneration in the parotid gland. Furthermore, the beginning of secretion of parotid saliva was retarded and both the volume flow and maximum bicarbonate concentration were markedly reduced.

Dog No. 4

Changes in chemical composition of blood and saliva: Serum amylase was $1,608 \mathrm{mg} / 100 \mathrm{ml}$ and $4,026 \mathrm{mg} / 100 \mathrm{ml}$ before and 28 hours after the operation, respectively.

The beginning of salivary secretion after injection of pilocarpine was from 3 minutes and 30 seconds preoperatively and 7 minutes postoperatively. As shown in Table 4, total volume of saliva was $29.3 \mathrm{ml}$ for 55 minutes $(0.53 \mathrm{ml}$ for a minute) preoperatively and $13.4 \mathrm{ml}$ for 60 minutes $(0.26 \mathrm{ml}$ for a minute) postoperatively. The maximum bicarbonate concentration was $67 \mathrm{mEq} / \mathrm{L}$ preopera- 
tively and $50 \mathrm{mEq} / \mathrm{L}$ postoperatively. No significant changes were seen on electrolytes before and after the operation.

Autopsy findings: A small quantity of bloody ascites was found in the abdominal cavity. The head and body of the pancreas were edematous and firm, being accompanied by fatty necroses. There were no abnormal findings in the tail of the pancreas. Both parotid glands were somewhat atrophic.

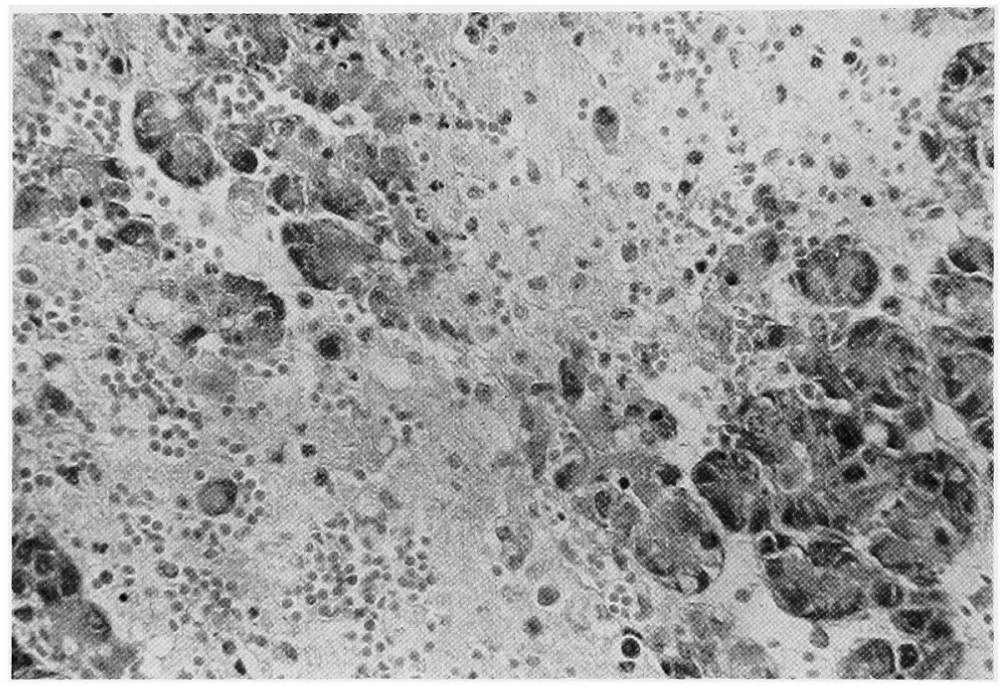

Fig. 7. Photomicrograph of the pancreatic head from Dog No. 4. Necrosis accompanied by bleeding is present. H.E. stain.

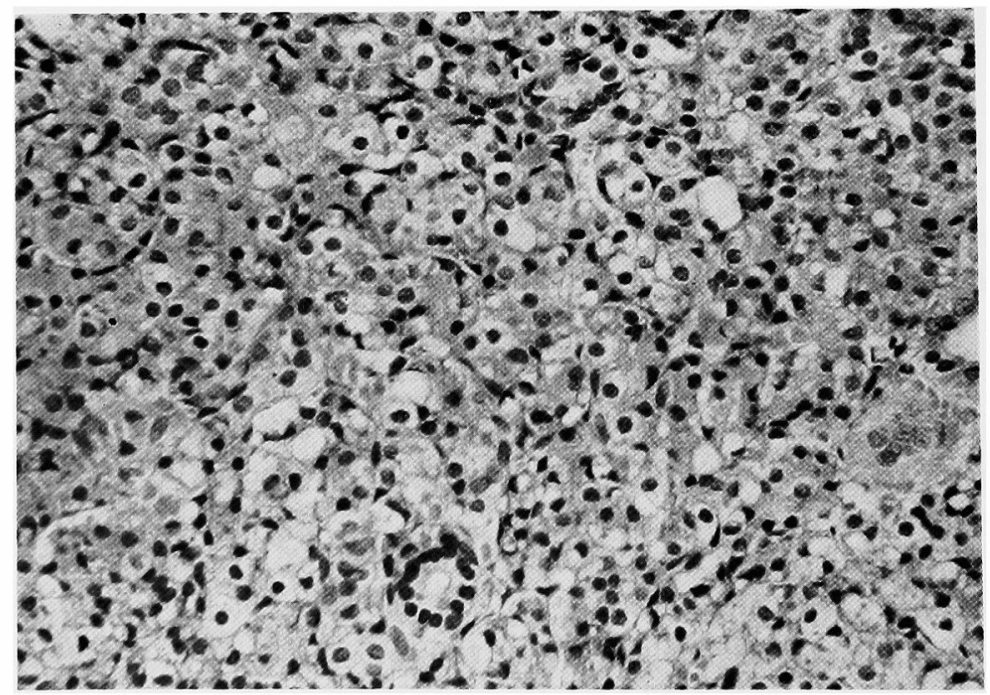

Fig. 8. Photomicrograph of the parotid gland from Dog No. 4. There are vacuolation and atypical arrangement of glandular cells. H.E. stain. 


\section{Histologic findings}

Pancreas: In the head of the pancreas, there were a marked edema and a few areas with necroses with infiltration of polynuclear cells (Fig. 7). In the body and tail of the pancreas, edema was also uniformly noticed.

Parotid glands: The vacuolation and atypical arrangement of glandular cells were noticed as seen in Dog No. 2 (Fig. 8).

The results in Dog No. 4 were summarized as follows. Histologically, necroses in the head of the pancreas and degenerative changes in the parotid gland were obviously noticed. The beginning of secretion of parotid saliva was retarded, volume flow was markedly reduced and the maximum bicarbonate concentration showed low values.

The results mentioned above lead to the following conclusions. When acute pancreatitis was produced in dogs, the parotid gland showed degenerative changes and the beginning of secretion of parotid saliva was retarded, and the volume and maximum bicarbonate concentration of the saliva were reduced.

\section{Discussion}

The authors have demonstrated in rats that degenerative changes in histologic findings and low amylase content of the parotid gland were induced in acute experimental pancreatitis (Kakizaki et al. 1971, $1972 \mathrm{a}, \mathrm{b}$ ). The present investigation was done to clarify the changes of bicarbonate content of parotid saliva of dogs with acute experimental pancreatitis.

For the measurement of the bicarbonate concentration, total carbon dioxide was determined by the method of Van Slyke et al. (1919). The total $\mathrm{CO}_{\mathrm{a}}$ measured was considered to be largely originated from bicarbonate (de Beer and Wilson 1932). It was found that the maximum bicarbonate concentration in parotid saliva was markedly reduced in dogs with acute pancreatitis.

Although there was a close relation between bicarbonate content and $\mathrm{pH}$ in saliva (Schneyer and Schneyer 1967), the regulation mechanism of the salivary concentration of bicarbonate itself has been difficult to identify. According to Schneyer and Schneyer (1967), bicarbonate of saliva can be derived from at least two sources: the cells of the salivary gland and the plasma. There are many evidences for a glandular source for salivary bicarbonate (Sand 1952, Coats and Wright 1957, Coats et al. 1958). Biochemical and histochemical studies (Van Goor 1948, Morris and Swayne 1964) have indicated significant carbonic anhydrase activity in many salivary glands, However, the results of studies on inhibitory effect of carbonic anhydrase on salivary bicarbonate and $\mathrm{pH}$ have been equivocal (Neidermeier et al. 1955, Chauncey and Weiss 1958, Yoshimura et al. 1959), so it may be assumed that a requirement for carbonic anhydrase in secretion of bicarbonate is not established at the present time (Schneyer and Schneyer 1967). On the other hand, there are also many experimental evidences indicating that salivary bicarbonate is derived from plasma bicarbonate (de Beer and Wilson 1932, 
MoClanahan and Amberson 1935, Sand 1952). However, it was reported that experimental metabolic acidosis gave inconsistent effects on the level of salivary bicarbonate (Sand 1952).

In the results of our present study it was worthy of note that bicarbonate concentration was decreased markedly in dogs with experimental acute pancreatitis despite of a constant value of $\mathrm{pH}$ in plasma and saliva. The decrease in salivary bicarbonate in these dogs may be caused by unknown mechanism, if any, which is related to degenerative changes of the parotid gland. And it was also noticed that the beginning of secretion of parotid saliva after pilocarpine injection was delayed and the volume flow of saliva was decreased in dogs with acute pancreatitis.

\section{References}

1) Andersen, O.S., Engel, K., Jorgeusen, K. \& Astrup, P. (1960) A micro method for determination of $\mathrm{pH}$, carbon dioxide tension, base excess and standard bicarbonate in capillary blood. Scand. J. clin. Lab. Invest., 12, 172-176.

2) Coats, D.A. \& Wright, R.D. (1957) Secretion by the parotid gland of the sheep: the relationship between salivary flow and composition. J. Physiol. (Lond.), 135, 611622 .

3) Coats, D.A., Denton, D.A. \& Wright, R.D. (1958) The ionic balances and transferences of the sheep's parotid gland during maximal stimulation. J. Physiol. (Lond.), 144, 108-122.

4) Chauncey, H.H. \& Weiss, P.A. (1958) Composition of human saliva. Parotid gland secretion: flow rate, $\mathrm{pH}$ and inorganic composition after oral administration of a carbonic anhydrase inhibitor. Arch. int. Pharmacodyn., 113, 377-383.

5) De Beer, D.J. \& Wilson, D.W. (1932) The inorganic composition of the parotid saliva of the dog and its relation to the composition of the serum. J. biol. Chem., 95, 671685.

6) Hald, P. (1947) The flame photometer for the measurement of sodium and potassium in biological materials. $J$, biol. Chem., 167, 499-514.

7) Kakizaki, G., Noto, N., Onuma, T., Saito, T. \& Izumi, S. (1971) Experimental study on the correlation between the pancreas and parotid gland, Ist Report: Effect of acute pancreatitis on the parotid gland from the view point of histologic finding and amylase level. Tohoku J. exp. Med., 105, 223-231.

8) Kakizaki, G., Noto, N., Fujiwara, Y., Oizumi, T., Soeno, T. \& Saito, T. (1972 a) Experimental study on the correlation between the pancreas and parotid gland, 2nd Report: Histologic findings and amylase content of the parotid gland of rats with recovery from acute pancreatitis. Tohoku J. exp. Med., 108, 141-153.

9) Kakizaki, G., Noto, N., Fujiwara, Y., Oizumi, T., Soeno, T. \& Saito, T. (1972 b) Experimental study on the correlation between the pancreas and parotid gland, 3rd Report: Histologic findings and amylase content of the pancreas and parotid gland of rats with experimental peritonitis or ileus. Tohoku J. exp. Med., 108, 155-164.

10) Kohn, J. (1962) Cellulose Acetate Electrophoresis and Immunodiffusion Techniques. Chromatographic and Electrophoretic Techniques. Vol. II. Zone electrophoresis by I. Smith \& W. Heinemann, 3rd Ed., Medical Books Ltd., London, p. 56.

11) McClanahan, H.H. \& Amberson, W.R. (1935) Bicarbonate elimination through the salivary glands under nervous and chemical stimulation. J. Pharmacol. exp. Therap., 53, $189-197$.

12) McGovern, J.J., Jones, A.R. \& Steinberg, A.G. (1955) The hematocrit of capillary blood. New Engl. J. Med., 253, 308-312.

13) Morris, G.C.R. \& Swayne, G.W. (1964) Histochemical studies of carbonic anhydrase in the salivary glands of rabbits. $J$. Physiol. (Lond.), 171, 5-6. 
14) Neidermeier, W., Stone, R.E., Dreizen, S. \& Spies, T.D. (1955) Effect of 2-acetylamino-1, 3, 4-thiadazole-5-sulfonamide (Diamox) on sodium, potassium, bicarbonate and buffer content of saliva. Proc. Soc. exp. Biol. Med., 88, 273-275.

15) Sand, H.F. (1952) Source of the bicarbonate of saliva. J. appl. Physiol., 4, 6676.

16) Schales, O.\& Schales, S.S. (1941) A simple and aceurate method for the determination of chloride in biological fluids. $J$. biol. Chem., 140, 879-884.

17) Schneyer, L.H. \& Schneyer, C.A. (1967) Inorganic composition of saliva. In: Handbook of Physiology, Section 6: Alimentary Canal, Volume II, Secretion, edited by C.F. Code \& W. Heidel, American Physiological Society, Washington, D.C. pp. 497-530.

18) Somogyi, M. (1938) Micromethods for the estimation of diastase. J. biol. Chem., 125, 399-414.

19) Tietze, F. \& Neurath, H. (1952) Light scattering studies on insulin. The minimum molecular weight of insulin. J. biol. Chem., 194, 1-13.

20) Van Goor, H. (1948) Carbonic anhydrase, its properties, distribution and significance for carbons dioxide transport. Enzymologia, 13, 73-164.

21) Van Slyke, D.D., Stillman, E. \& Cullen, G.E. (1919) Studies of acidosis. XIII. a method for titrating the bicarbonate content of the plasma. J. biol. Chem., 33, $167-178$.

22) Yoshimura, H., Iwasaki, H., Nishikawa, T. \& Matsumoto, S. (1959) Role of earbonic anhydrase in the bicarbonate excretion from salivary glands and mechanism of ionic excretion. Jap. J. Physiol., 9, 106-123. 